\title{
A Narrative Review: Risk Factors of Low Back Pain in Military Personnel/Recruits
}

\author{
Ebby Waqqash $^{1 *}$, Eliza Hafiz ${ }^{1}$, Mohamad Shariff A Hamid ${ }^{2}$ \& Ali Md Nadzalan ${ }^{3}$ \\ ${ }^{1}$ Sports Centre, University of Malaya, Malaysia. \\ ${ }^{2}$ Faculty of Medicine, University of Malaya, Malaysia. \\ ${ }^{3}$ Faculty of Sports Science and Coaching, Universiti Pendidikan Sultan Idris, Malaysia. \\ *Corresponding author E-mail: ebbywaqqash@hotmail.com
}

\begin{abstract}
Military personnel are one of the occupations at high risk of developing low back pain (LBP) due to its job demands. Low back pain (LBP) is a major cause of morbidity and lost from work among military personnel. This narrative review was conducted to determine the risk factors of LBP in military personnel/recruits. Searches focusing on causal comparative and epidemiology studies using OVIDMedline, CINAHL, SPORTDiscus, PubMed, and Scopus databases from year January 1950 to April 2018. The Preferred Reporting Items for Systematic reviews and Meta-Analyses (PRISMA) guidelines was used to select and synthesis of studies. The strongest personal risk factors identified were history of LBP $(\mathrm{OR}=8.91, \mathrm{CI}=1.71-46.5)$, female gender (OR: 6.59, CI 1.79 - 24.24), aerobic exercise involvement $(\mathrm{OR}=4.39$, $\mathrm{CI} 1.53-12.57)$ and older age (OR 4.16). The strongest occupational risk factors identified were prolonged hours of flight per day ( $\mathrm{OR}=11.3$, CI $5.2-24.8)$, driving in forward bending posture ( $\mathrm{OR}=3.63$, CI $1.06-12.42)$, branch of services (Army; OR 2.74, CI 2.60-2.89 \& Air Force; 1.98, CI 1.84 -2.14), Night training (OR = 1.8-2.0, CI 1.1 - 3.1) and whole-body vibration exposure (OR 1.94, CI 1.02 -3.69). The strongest psychosocial risk factors identified were worries $(\mathrm{OR}=5.47$, CI 1.70- 17.62), no support from others $(\mathrm{OR}=4.0$, CI $1.31-12.34)$ high work stress $(\mathrm{OR}=3.47$, CI $1.31-12.34)$, depression $(\mathrm{OR}=1.75$, CI $1.08-2.83)$, and psychological stress (OR 1.71). This review summarizes the personal, occupational and psychosocial risk factors associated with LBP among military personnel/ recruits. LBP risk factors differs based on the military branch of services and job scope. Primary LBP risk factor for Air Force pilots, helicopter pilots and military vehicle drivers LBP is sitting ergonomics. Primary LBP risk factor for army (i.e. combat infantry) identified are occupational physical exposure (military training, heavy lifting and carrying, patrol durations.) Further studies are required to verify if there is any interaction between personal, occupational, and psychos ocial LBP risk factor categories among military personnel/recruits.
\end{abstract}

Keywords: Risk factor, low back pain, lumbar pain, military personnel.

\section{Introduction}

Low back pain (LBP) is one of the most common health problems among general population and working professionals [1]. It is believed that most workers experienced symptoms of low back pain during their working life. According to Vahdati et al. [1], $94.4 \%$ of affected individuals believed that their low back pain was associated to their current job and $72.6 \%$ claimed that their lower back pain symptoms occurred upon starting their profession. According to the literature, the three general categories of LBP risk factor identified: personal (related with the individual influencing them to the disorder e.g.: age, gender, genetics etc.), psychosocial (related with organizational work practice on mental and emotional health e.g. job insecurity, stress, etc.) and occupational (related with the physical work task e.g. repetition, force, etc.). Occupational factor is a modifiable LBP risk factor which should be taken into consideration in LBP prehabilitation for occupation with high risks for LBP $[2,3]$.

Military personnel are one of the occupations at high risk of developing LBP due to its job demands. LBP is a major prevalent cause of morbidity and lost from work among military personnel [4]. In a systematic review, Cohen et al. [5] reported that the low back region contributes the highest primary complaints of spinal pain among military personnel compared to upper back, and neck regions with approximately $75 \%$ prevalence. It has also been stated that the occupational risk factors for LBP among military personnel were poor ergonomics, body armour usage, heavy carrying and lifting, prolonged standing, exposure to body shock and vibration, awkward sitting postures, combat training, marching and military exercises [5].

There have been studies which reported low back pain prevalence and risk factors among military personnel in different countries. Mattila et al. [6] conducted a retrospective cohort study from 1990 to 2002 on the incidence of LBP hospitalisation among Finnish military conscripts. They discovered that 5961 (1.3\%) of Finnish male conscripts were hospitalised for LBP throughout their military service. The overall incidence rate of LBP incidence was 27.0 per 1000 person-years $(95 \%, \mathrm{CI}=25.7-28.2)$. A retrospective cohort study on the risk factors of low back pain among Danish soldiers from 2003 to 2005 was conducted by Nissen et al. [7]. A total of 175 soldiers $(26 \%)$ have been reported to have LBP. The risk factors for LBP identified was older age $(p=0.016)$, less support from leaders (odds ratio $[\mathrm{OR}]=1.69, \mathrm{p}=0.019$ ), psychological stress $(\mathrm{OR}=1.71, \mathrm{p}=0.009)$, awkward working positions (OR $=1.98, \mathrm{p}=0.001)$, and working in depots or storehouses $(\mathrm{OR}=$ 2.60, $\mathrm{p}=0.041)$ (Nissen, 2014). Monnier et al. [8] also reported 
that low back pain (36\%) as one of the most common musculoskeletal pain among Swedish armed forces (SAF) marines. LBP functional disability was found to be significantly associated with physical training $\leq 1$ day/week (OR 5.3, 95\% CI 1.7 to 16.8), body height $\leq 1.80 \mathrm{~m}$ (OR 5.0, 95\% CI 1.6 to 15.1$)$ and $\geq 1.86 \mathrm{~m}$ (OR $4.4,95 \%$ CI 1.4 to 14.1 ), and computer work $1 / 4$ of the working day (OR 3.2, 95\% CI 1.0 to 10.0 ) and $\geq 1 / 2$ (OR 3.3, 95\% CI 1.1 to 10.1). On the other hand, Knox et al. [9] and Gubata et al. [4] investigate the risk factors for LBP among United States (US) military personnel. Knox et al. [9] discovered that risk factors for LBP among US military personnel includes increasing age (> 40year age group has incidence rate ratio of 1.28 as compared to 2029 years of age group), division of services (incidence rate ratio comparison to marines as reference; army 2.19, navy: 1.02 and air force 1.54), and marital status (married service members has incidence rate ratio of 1.21). Gubata et al. [4] stated that the most common low back pain risk factors among US enlisted soldiers and marines were overweight (odds ratio [OR]: 1.17; [95\% CI] 1.12-1.23), obese (OR: 1.35 ; 95\% CI: 1.26-1.44), 25- 29 years (OR: 1.23 ; 95\% CI: 1.16-1.31), 30 years or older (OR: 1.43; 95\% CI: 1.34-1.52), and history of a back diagnosis at the preenlistment medical examination (OR: 1.94; 95\% CI: 1.50-2.50), deploying once (OR: 1.09 ; 95\% CI: 1.05-1.14)

According to Govindu and Babski-Reeves [2], previous research has identified three primary risk factor categories for LBP (occupational, personal and psychosocial factors) for the general population. Nevertheless, the risk factors for military population might be different from the general population due to their job scope. Even though there have been some studies on risk factors of LBP among military personnel, there is limited comprehensive reviews on musculoskeletal injuries particularly low back injuries among military population (Bulzacchelli, 2014). Thus, the aim of this article is to determine the risk factors of low back pain in military personnel/recruits.

Table 1: Search strategy for EBSCOhost (Medline, CINAHL, SPORTdiscus) for year January 1950- April 2018

\begin{tabular}{|l|l|}
\hline Keywords & Results \\
\hline 1. Risk Factor* & $1,690,306$ \\
\hline 2. Risk assessment* & 457,331 \\
\hline 3. Odds ratio & 497,730 \\
\hline 4. Causation & 58,934 \\
\hline 5. Etiology* & $1,989,251$ \\
\hline 6. 1 OR 2 OR 3 OR 4 OR 5 & $3,690,794$ \\
\hline 7. Low back pain & 79,213 \\
\hline 8. Lumbar pain & 22,911 \\
\hline 9. Nonspecific* low back pain & 3,947 \\
\hline 10. OR 8 OR 9 & 89,937 \\
\hline 11. Military personnel* & 42,056 \\
\hline 12. Soldier* & 52,121 \\
\hline 13. Army* & 123,888 \\
\hline 14. Marine* & 230,831 \\
\hline 15. Air force & 36,430 \\
\hline 16. 11 OR 12 OR 13 OR 14 OR 15 & 415,274 \\
\hline 17. 6 AND 10 AND 16 & 1,966 \\
\hline
\end{tabular}

\section{Method}

\subsection{Data Sources:}

Searches were conducted electronically using OVIDMedline, CINAHL, SPORTDiscus, PubMed, and Scopus databases from year January 1950 - April 2018. Only studies which were published in English were considered as there are limited resources for translation. There was no communication with study authors but electronic searching was complemented by revising references of included studies and reviewing references from previous systematic reviews on similar topics to uncover studies that may have been overlooked by the search strategy. In addition, several articles were hand searched in local library in Malaysia for additional references. The search strategies used for EBSCOhost database are displayed in table 1. Similar search strategy was conducted for other databases (OVIDMedline, CINAHL, SPORTdiscus and PubMed).

\subsection{Study Selection:}

This narrative review includes 1) justification of study selection criteria 2) search approaches to identify related studies, 3) comprehensive analysis of the selected studies and 4) discussion of the findings of the review. The Preferred Reporting Items for Systematic reviews and Meta-Analyses (PRISMA) guidelines was used to select and synthesis of studies. The study selection was based on the following eligibility criteria:

The inclusion criteria were as follows:

Published in English language

Type of study design used:

Random controlled trial study

Quasi-experimental study

Cross sectional study

Case-control study

Related to low back pain or lumbar pain.

Personal, psychosocial and occupational exposure of

low back pain

Population:

Human studies

Age group: 18-60 years old

Occupation: military armed forces (i.e. army/soldier, air force, navy)

The exclusion criteria (preclude) were as follows:

Systematic reviews and meta-analysis.

Studies which do not report on lumbar back pain as come measures.

Studies investigating other than lumbar back pain (cer- vical, thoracic and whole spine pain) Studies investigating the efficacy of low back pain treatment.

Health services research (e.g., costs of injuries)

\subsection{Data Extraction}

The titles and abstracts of studies retrieved from the searches were reviewed following criteria for study inclusion in deciding if the full-text of the manuscript were required for further evaluation. Each full text manuscript was systematically evaluated according to the

a) Study objective/s

b) Study design (cross-sectional, case-control, prospective cohort).

c) iii. Study population and setting (country, employer, industry, occupation).

d) Type of risk factors (definition, measurement, level of exposure).

e) Type of LBP outcome (definition, type, severity, as- sessment period, health-care use, sick leave).

f) Type of analysis (statistical methods, univari-ate/multivariate, adjusting for confounders)

g) Measures of association (confidence interval, odds ratio, relative risk) with confidence interval or raw data necessary to calculate these measures of association.

h) Study funding source and reported author conflicts of interest.

\section{Results}

A total of 2219 original articles were identified from the five selected databases and cross referencing, of which 1882 duplicates were removed. Following screening of manuscript titles and abstracts, a total of 105 articles full text were retrieved and assessed 
for eligibility. Of these 72 articles were excluded as they did not fulfil our selection criteria.

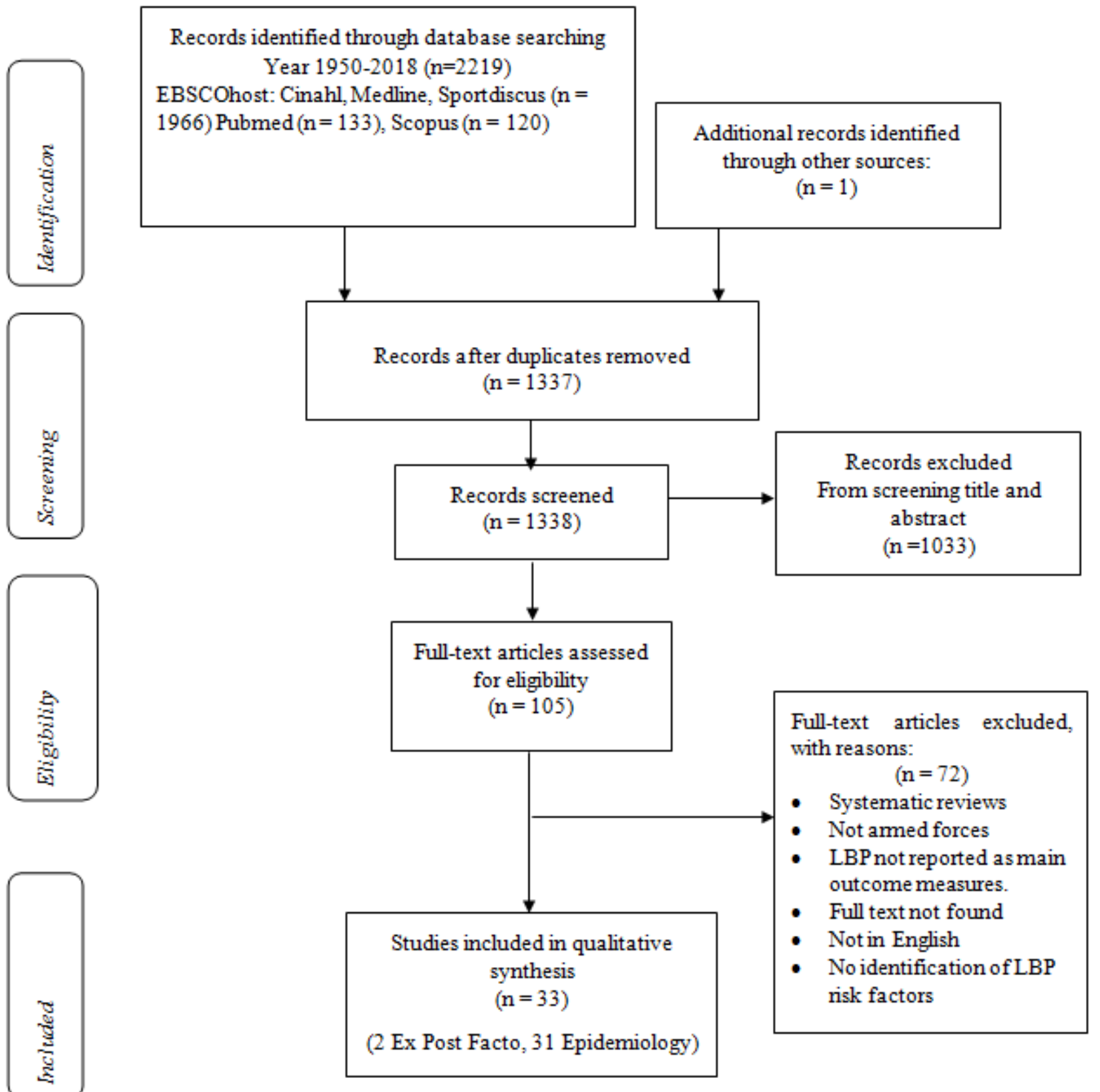

Figure 1: PRISMA flow diagram for study selection

In this review 33 studies was identified and included, of which two were causal-comparative studies (Ex Post Facto) and 31 were epidemiology studies (i.e. cross-sectional, cohort studies) (Refer at Table 2 and Table 3: in the appendix).

Gao et al. [10] investigate the effects of sudden load changes (expected and unexpected imbalance) on the activity rapid reaction time (RRT) and intensity rapid reaction (IRR) of bilateral lumbar erector spinae (ES) and multifidus (MF) in military personnel with or without chronic low back pain (LBP) muscles. Gao et al. [10] concluded that military recruits with chronic LBP associated with military training had increased reaction time and activation amplitude of lumbar erector spinae and multifidus when compared with their healthy counterparts.

Seay et al. [11] compared trunk and pelvis range of motion (ROM) between individuals with history of LBP (HBP) and no history of LBP (NBP) during sustained lifting and lowering task. They discovered that during the 9th minute the ROM decreases for NBP $(21.6 \pm 6$ deg, $p<0.05)$ but no changes in ROM was found in
HBP group which is most likely due to protective lifting mechanics by HBP group.

Study region: In the 31 epidemiology studies examined; 23 studies were from European countries (United States $=17$, Finland $=3$, Denmark $=1$, Sweden $=1$, and Norway $=1$ ), two studies from Middle East countries studies (Israel $=1$, Turkey $=1$ ), and four studies from Asian countries $($ China $=2$, Malaysia $=1$, Korea $=1$ ). Two studies did not mention the region where the studies were conducted $[14,15]$.

Classification of personal, occupational and psychosocial LBP risk factors: Epidemiological studies were reviewed and risk factors were classified as personal, occupational and psychosocial (Refer Table 4: in the appendix)

The personal risk factors identified were age (25-29 y/o), older age (>36 y/o), traces of G allele of CASP-9 \& T allele of GDF5 genes, female gender, low education level higher education level, health status, history of LBP, lower extremity injury, body height $\geq 1.86 \mathrm{~m}$, race (blacks), married, longer service time, rare/never involved in aerobic exercise, tobacco use (smoking or smokeless), 
alcohol use, BMI (obese), poor fitness level, low aerobic endurance, low trunk muscle endurance, poor push up scores, sports participation, and statin usage. The occupational risk factors identified were active duty, combat deployment, junior enlisted rank (privates), higher ergonomic exposure, work positions (awkward), work station (depots/storehouses), army service, forward bend sitting posture, Jet fighter pilots flight hours, long hours of flight per day (>2000 hours), whole body vibration, occupational driving, night training, cross country race, grenade throwing, military training, lifting, strength training, body armour, duration body armour usage, weight of equipment worn, and patrol duration. The psychosocial risk factors identified were worries, low moral support, high work stress, increased peer cohesion, greater perceived effort at work, general distress, mental health, sleep disorders, depression, leader social support, psychological stress, and psychological problems.

There are few studies with conflicting evidences; Nelson et al. [31] claimed that older age (>36 y/o) are more exposed to LBP, however, Gubata et al. [4] stated that age 25-29-year-old were more susceptible to LBP. For education level; Feuerstein et al. [16] reported that higher education level have significant association with LBP, nonetheless Taanila et al. [19] in contrast discovered that lower education level were more related with LBP. As for gender, Orsello et al. [33] reported that male has higher association to LBP as compared to females, conversely, other studies has suggested females are more prone to LBP $[9,13,16,25,26]$.

Occupational LBP Risk factors in different branch of services: In this review, LBP risk factors differs based on the military branch of services and job scope. It is hypothesized that jet fighter pilots, helicopter pilots and military vehicle drivers are more susceptible to LBP because of sitting as part of their job scope. It has been identified forward bend sitting posture, occupational driving, Jet fighter pilots flight hours, long hours of flight per day $(>2000$ hours), whole body vibration as one of the contributing risk factors of LBP [14, 20-23, 26, 36].

Contrary with the jet fighter pilots and helicopter pilots, LBP are most likely caused by occupational physical exposure in the army particularly the combat infantry. The occupational risk factors identified among army infantry includes combat deployment, night training, cross country race, grenade throwing, military training, lifting, strength training, body armour, duration body armour usage, weight of equipment worn, and patrol duration [24 $30,31,34,35]$

\section{Discussion}

\subsection{Personal Risk Factors of LBP in the Military}

History of low back injury is also one of the strongest risk factors for LBP recurrence. Monnier et al. [12] reported that the previous back pain injury has odds ratio of 2.99 at 6 and 6.75 at 12 months postinjury respectively. In addition to LBP history, lower extremities pain (hip, knee or foot) also has been reported to be a LBP predictor within duration of 6 months (OR; 2.32, CI; 1.02-5.24). Monnier et al. [12] theorized that the past history of LBP might cause musculoskeletal disorders leading to reduced muscle strength, joint stability and proprioception deficiencies. The insufficiencies in muscle strength and joint stability might affect optimal spinal loading, and therefore predispose marines with future LBP episodes. Another contributing factor for LBP in military personnel is body height. Monnier et al. [12] reported that marines with a body height of 1.86 or more is at risk of having LBP within 6 (OR 2.81, $95 \%$ CI 1.16- 6.84) and 12 months (OR 2.75, $95 \%$ CI 1.21-6.29). It was also highlighted by Gubata et al. [4] that being overweight (BMI 25-30; OR: 1.17; 95\% CI: 1.12-1.23) and obese (BMI > 30; OR: 1.35; 95\% CI: 1.26-1.44) has higher risk of developing LBP. According to Taanila et al. [40], being overweight and obese may disrupt the kinetic chain of movement which may lead to higher risk of musculoskeletal injuries particularly low back pain. Past studies have shown that LBP prevalence in military personnel differs with different age ranges with higher prevalence in older recruits. Bar-Dayan et al. [41] reported that LBP prevalence in 17- year old Israeli military recruits were low with only prevalence of $17 \%$ out of 828,171 recruits. Furthermore, Knox et al. [9] discovered that senior rank officers age 40 years and above has incidence rate ratio of 1.28 as compared to 20-29 years personnel. This is likely due to cumulative effect through time of service as senior military personnel has longer exposure of physical load than junior military personnel. Earlier studies have also reported effects of gender on the development of low back pain [42, 43]. Bar-Dayan et al. [41] (OR $=1.93$, CI 1.89-1.98), Feuerstein et al. [16] $(\mathrm{OR}=6.59$, CI $1.79-24.24)$, Knox et al. [9] $(I R R=1.45)$ has discovered that females has increased low back pain risk as compared to their male counterparts. Knox et al. [9] proposed the theory of increase of LBP in female genders may be due to estrogen hormone exposure which alters the responses to pain. In regards to health behaviours, there were association between detrimental health behaviours (smoking and drinking habits) with LBP [29]. Smoking and drinking habits may cause a decrease in bone density which impairs fibroblast function and hinders wound and fracture healing [40]. Physical fitness is one of the essential component in prevention of musculoskeletal injuries (including LBP) among the military population. According to Knapik et al. [44], low physical fitness as potential risk factors for musculoskeletal injuries in the infantry soldiers. Knapik et al. [44] reported that the slowest quartile of 2-mile run in infantry soldiers has 1.6 times greater risk of musculoskeletal injuries. According to Taanila et al. [40], it is suggested that military personnel with low aerobic fitness levels may fatigue more rapidly and may lead to changes in gait and kinematics which results in musculoskeletal strain on different body parts, increasing the rate of injuries. In addition, population with lowest repetitions quartile of sit-ups has 1.9 times greater risk of LBP injury. This finding supports the importance of core strength and stability to protect against LBP. According to Taanila et al. [40], improved neutral lumbar neutral zone control in trunk muscles helps decreases LBP among middleaged men.

\subsection{Occupational Risk Factors of LBP in the Military}

Work ergonomics is important to ensure people are working efficiently in their working environment. Sitting ergonomics are one of the main risk factors for military pilots. According to Games et al. [45], military helicopter pilots are required to sit on unpadded, UH-60 pilot's seat for 4 hours while performing multiple cognitive task. Games et al. [45] discovered that after 4 hours of restricted sitting position, military helicopter pilots have increase subjective discomfort (30.27-point increase), increase in LBP intensity (8.53-point increase), decrease lower extremity sensory function, and decrease lateral and anterior leg skin temperature $\left(2.78^{\circ} \mathrm{C}-2.85^{\circ} \mathrm{C}\right.$ decrease $)$. This finding clearly indicates that prolonged sitting in a UH-60 seat increases discomfort in low back and lower extremities possibly via peripheral nervous system mechanism. According to Grossman et al. [46], there is also association between LBP and types of aircrafts. Grossman et al. [46] reported the LBP prevalence of $89.38 \%$ among utility pilot, $74.55 \%$ among attack helicopter pilots and $64.02 \%$ among fighter pilots. It is important explore aviation factors associated with back pain because: (1) back pain is one of the main causes for workdays lost, (2) to develop preventive methods to reduce LBP prevalence specific to the aircraft types based on frequency and severity of complaints in the particular aircraft [46]. Unlike military pilots, the main LBP risk factor for army particularly the combat infantry is occupational exposure. According to Roy et al. [35], heavy lifting of military equipment, prolonged body armour usage, and long duration of patrol are associated with moderate or severe LBP in combat army infantry. Cohen et al. [5] stated that lifting 
objects are the most common cause of injury in patients medically evacuated for LBP (18\%). In addition, Roy et al. [35] emphasized that carrying heavy loads on the back induces excessive forward trunk lean resulting in uneven distribution of stress to the spine and intervertebral disc, thus making the lumbar spine highly susceptible to injuries. The co-activation of the trunk muscles can stabilize the spine nevertheless as the load increases or fatigue has been reached, soldiers are unable to sustain the optimal muscle contractions.

\subsection{Psychosocial Risk Factors of LBP in the Military}

Individuals mental health is a risk factor for musculoskeletal injuries particularly LBP which is often overlooked by medical practitioners. Previous studies have shown that psychiatric comorbidity increases LBP in military population [7]. Feuerstein et al. [16] conducted a case-control study $(\mathrm{n}=421)$ investigating the association of sociodemographic factors, health behaviour, ergonomic, workplace and individual psychosocial factors with lost time in soldiers with LBP. They reported individuals who perceived the work situation as stressful $(\mathrm{OR}=3.47, \mathrm{CI}=1.24-9.74, \mathrm{p}<0.05)$ has the strongest psychosocial association to LBP. This finding was supported by Nissen et al. [7] in which they discovered that there is moderate association between psychological stress and LBP $(\mathrm{OR}=1.71, \mathrm{p}=0.009)$. According to Nissen et al. [7], studies in civilian cohorts, also shows similar findings in which there is strong relationship between self-reported stress and LBP. Feuerstein et al. [17] developed a model which suggested ergonomic exposure (heavy lifting \& carrying, prolonged sitting \& standing, repetitive bending, pushing $\&$ pulling) does not directly influence LBP clinic visits but affects the military personnel work environment perception which are related to LBP clinic visits. They reported that high level of ergonomic exposures is related to increased job stress, higher job stress is linked to high levels of general distress, and general distress and smoking were associated to LBP clinic visits. It was hypothesized that the psychosocial risk factors for LBP are mostly secondary; associated with behaviours which could lead to LBP. The behavioural changes include, changes in posture (sitting, standing posture), inactivity (sedentary behaviour) and hypersensitivity (experience physical sensations more than those healthy counterparts) [17].

\section{Conclusion}

This review summarizes the personal, occupational and psychosocial risk factors associated with LBP among military personnel/ recruits. The personal risk factors include age (25-29 y/o), older age ( $>36 \mathrm{y} / \mathrm{o})$, genetics, female gender, male gender, low education level, higher education level, health status, history of LBP, lower extremity injury, tall body height $(\geq 1.86 \mathrm{~m})$, race (blacks), marital status (married), longer service time, rare/never aerobic exercise involvement, smoking, tobacco use, alcohol use, smokeless tobacco usage, physical health, BMI (obese), poor fitness level low aerobic endurance, low trunk muscle endurance, poor push up scores, sports participation, and statin usage. The occupational risk factors identified were active duty, deployment, combat deployment, rank (junior enlisted), higher ergonomic exposure, work positions (awkward), work station (depots/storehouses), rank (privates), branch of service (army), forward bend sitting posture, +GZ flight hours, hours of flight per day, whole body vibration, prolonged flying time ( $>2000$ hours), occupational driving, night training, cross country race, grenade throwing, military training, lifting, strength training, body armour, duration body armour usage, weight of equipment worn, and patrol duration. The psychosocial risk factors identified were worries, low moral support, high work stress, increased peer cohesion, greater perceived effort at work, general distress, mental health, sleep disorders, depression, leader social support, psychological stress, and psychological problems. Most studies identified in this review only investigates the relationship of the three risk factor categories (personal, occupational, and psychosocial) on LBP. Based on this review, only one study [17] examined the interaction of these risk factor categories on LBP. Further studies are required to verify if there is any interaction between this three risk factor categories.

\section{References}

[1] Shams Vahdati, S., et al., Evaluation of Prevalence of Low Back Pain Among Residents of Tabriz University of Medical Sciences in Relation with Their Position in Work. Turkish Journal of Emergency Medicine, 2014. 14(3): p. 125-129.

[2] Govindu, N.K. and K. Babski-Reeves, Effects of personal, psychosocial and occupational factors on low back pain severity in workers. International Journal of Industrial Ergonomics, 2014. 44(2): p. 335-341.

[3] Mendelek, F., et al., On the quantitative relationships between individual/occupational risk factors and low back pain prevalence using nonparametric approaches. Joint Bone Spine, 2011. 78(6): p. 619 624.

[4] Gubata, M.E., et al., Risk factors for back-related disability in the US army and marine corps. Spine, 2014. 39(9): p. 745-753.

[5] Cohen, S.P., et al., Spine-area pain in military personnel: a review of epidemiology, etiology, diagnosis, and treatment. The Spine Journal: Official Journal Of The North American Spine Society, 2012. 12(9): p. 833-842.

[6] Mattila, V.M., et al., Incidence and trends of low back pain hospitalisation during military service - An analysis of 387,070 Finnish young males. BMC Musculoskeletal Disorders, 2009. 10.

[7] Nissen, L.R., et al., Deployment-related risk factors of low back pain: a study among danish soldiers deployed to Iraq. Military Medicine, 2014. 179(4): p. 451-458.

[8] Monnier, A., et al., Musculoskeletal pain and limitations in work ability in Swedish marines: A cross-sectional survey of prevalence and associated factors. BMJ Open, 2015. 5(10).

[9] Knox, J., et al., The incidence of low back pain in active duty United States military service members. Spine (03622436), 2011. 36(18): p. 1492-1500.

[10] Gao, Y., et al., Adaptation of muscles of the lumbar spine to sudden imbalance in patients with lower back pain caused by military training. The Journal Of Spinal Cord Medicine, 2014. 37(6): p. 774-781.

[11] Seay, J.F., et al., A history of low back pain affects pelvis and trunk mechanics during a sustained lift/lower task. Ergonomics, 2013. 56(6): p. 944-953.

[12] Monnier, A., et al., Risk factors for back pain in marines; a prospective cohort study. BMC Musculoskeletal Disorders, 2016. 17: p 319-319.

[13] Bar-Dayan, Y., et al., Back disorders among Israeli youth: A prevalence study in young military recruits. Spine Journal, 2012. 12(9): p 749-755.

[14] Bongers, P.M., et al., Back pain and exposure to whole body vibration in helicopter pilots. Ergonomics, 1990. 33(8): p. 1007-1026.

[15] Ernat, J., et al., Incidence and risk factors for acute low back pain in active duty infantry. Military Medicine, 2012. 177(11): p. 13481351.

[16] Feuerstein, M., et al., Working with low back pain: workplace and individual psychosocial determinants of limited duty and lost time. American Journal Of Industrial Medicine, 2001. 40(6): p. 627-638.

[17] Feuerstein, M., et al., How do job stress and ergonomic factors impact clinic visits in acute low back pain? A prospective study. Journal of Occupational and Environmental Medicine, 2006. 48(6): p. 607-614.

[18] George, S.Z., et al., Predictors of occurrence and severity of first time low back pain episodes: findings from a military inception cohort. Plos One, 2012. 7(2): p. e30597-e30597.

[19] Taanila, H.P., et al., Predictors of low back pain in physically active conscripts with special emphasis on muscular fitness. The Spine Journal: Official Journal Of The North American Spine Society, 2012. 12(9): p. 737-748.

[20] Hämäläinen, O., Thoracolumbar pain among fighter pilots. Military Medicine, 1999. 164(8): p. 595-596

[21] Hansen, O.B. and A.S. Wagstaff, Low back pain in Norwegian helicopter aircrew. Aviation, Space, And Environmental Medicine, 2001. 72(3): p. 161-164. 
[22] Hermes, E.D.A., T.S. Webb, and T.S. Wells, Aircraft type and other risk factors for spinal disorders: Data from 19,673 military cockpit aircrew. Aviation Space and Environmental Medicine, 2010. 81(9): p. 850-856.

[23] Honkanen, T., et al., Functional test measures as risk indicators for low back pain among fixed-wing military pilots. J R Army Med Corps, 2017. 163(1): p. 31-34.

[24] Hou, Z.-h., et al., Prevalence of low back pain among soldiers at an army base. Chinese Medical Journal, 2013. 126(4): p. 679-682.

[25] Knox, J.B., J.R. Orchowski, and B. Owens, Racial differences in the incidence of acute low back pain in United States military service members. Spine (03622436), 2012. 37(19): p. 1688-1692.

[26] Knox, J.B., et al., Occupational driving as a risk factor for low back pain in active-duty military service members. The Spine Journal: Official Journal Of The North American Spine Society, 2014. 14(4): p. $592-597$.

[27] Seay, J.F., et al., Lower Extremity Injury Increases Risk of Firsttime Low Back Pain in the U.S. Army. Medicine And Science In Sports And Exercise, 2017

[28] Kang, S.H., et al., Military rank and the symptoms of lumbar disc herniation in young Korean soldiers. World Neurosurgery, 2014. 82(1-2): p. e9-e14.

[29] Kardouni, J.R., T.L. Shing, and D.I. Rhon, Risk Factors for Low Back Pain and Spine Surgery: A Retrospective Cohort Study in Soldiers. American Journal Of Preventive Medicine, 2016. 51(5): p. e129-e138.

[30] Mu, J., et al., Analysis of association between IL-1, CASP-9, and GDF5 variants and low-back pain in Chinese male soldiers: Clinical article. Journal of Neurosurgery: Spine, 2013. 19(2): p. 243-247.

[31] Nelson, D.A., N. Menzel, and P. Horoho, Prior depression and incident back pain among military registered nurses: A retrospective cohort study. International Journal of Nursing Studies, 2017. 74: p 149-154.

[32] O'Connor, F.G. and S.S. Marlowe, Low back pain in military basic trainees. A pilot study. Spine, 1993. 18(10): p. 1351-1354.

[33] 33. Orsello, C.A., A.S. Phillips, and G.M. Rice, Height and in flight low back pain association among military helicopter pilots. Aviation Space and Environmental Medicine, 2013. 84(1): p. 32-37.

[34] Roy, T.C. and H.P. Lopez, A comparison of deployed occupational tasks performed by different types of military battalions and resulting low back pain. Military Medicine, 2013. 178(8): p. e937-e943.
[35] Roy, T.C., H.P. Lopez, and S.R. Piva, Loads worn by soldiers predict episodes of low back pain during deployment to afghanistan. Spine (03622436), 2013. 38(15): p. 1310-1317.

[36] Rozali, A., et al., Low back pain and association with whole body vibration among military armoured vehicle drivers in Malaysia. Med J Malaysia, 2009. 64(3): p. 197-204.

[37] Secer, M., et al., Nonspecific low back pain in a group of young adult men. Turkish Neurosurgery, 2011. 21(2): p. 135-139.

[38] Tvaryanas, A.P., et al., Statins and Musculoskeletal Conditions in U.S. Air Force Active Duty Service Members. Military Medicine, 2017. 182(9): p. e1938-e1945.

[39] Mattila, V.M., et al., Low back pain and its risk indicators: a survey of 7,040 Finnish male conscripts. European Spine Journal: Official Publication Of The European Spine Society, The European Spinal Deformity Society, And The European Section Of The Cervical Spine Research Society, 2008. 17(1): p. 64-69.

[40] Taanila, H., et al., Aetiology and risk factors of musculoskeletal disorders in physically active conscripts: a follow-up study in the Finnish Defence Forces. BMC Musculoskeletal Disorders, 2010. 11 p. 146-146.

[41] Bar-Dayan, Y., et al., Degenerative disease in lumbar spine of military parachuting instructors. Journal Of The Royal Army Medical Corps, 2003. 149(4): p. 260-264.

[42] Roy, T.C., et al., Heavy Loads and Lifting are Risk Factors for Musculoskeletal Injuries in Deployed Female Soldiers. Military Medicine, 2016. 181(11): p. e1476-e1483.

[43] Schoenfeld, A.J., et al., Incidence and risk factors for lumbar degenerative disc disease in the United States Military 1999-2008. Military Medicine, 2011. 176(11): p. 1320-1324.

[44] Knapik, J., et al., Physical fitness, age, and injury incidence in infantry soldiers. Journal of Occupational Medicine, 1993. 35(6): p 598-603.

[45] Games, K.E., et al., Prolonged restricted sitting effects in UH-60 helicopters. Aerospace Medicine and Human Performance, 2015. 86(1): p. 34-40

[46] Grossman, A., et al., Back symptoms in aviators flying different aircraft. Aviation, Space, And Environmental Medicine, 2012. 83(7): p. 702-705.

\section{Appendix}

Table 2: Summary of causal comparative studies (Ex Post Facto)

\begin{tabular}{|c|c|c|c|c|}
\hline No. & $\begin{array}{l}\text { Author } \\
\text { (s) }\end{array}$ & Sociodemographic & Results & Conclusion \\
\hline 1 & $\begin{array}{l}\text { Gao et al. } \\
{[10]}\end{array}$ & $\begin{array}{l}\mathrm{N}=42 \\
21 \text { LBP male \& } 21 \text { healthy } \\
\text { male } \\
\text { Active members of the Nanjing } \\
\text { Military Region land forces } \\
\text { Setting: The 117th PLA } \\
\text { Hospital, Hangzhou, China }\end{array}$ & $\begin{array}{l}\text { Core activation amplitude increased } \\
\text { When compared to healthy individuals, LBP patients } \\
\text { has greater ipsilateral \& contralateral erector spinae } \\
\text { (ES) and multifidus (MF) during imbalance condi- } \\
\text { tions } \\
\text { Ipsilateral ES: } 2.90 \pm 1.68 \text { vs. } 1.77 \pm 0.75, \mathrm{P}=0.001 \\
\text { Ipsilateral MF: } 5.18 \pm 7.35 \text { vs. } 2.00 \pm 1.00, \mathrm{P}=0.010 \\
\text { Contralateral ES: } 5.02 \pm 4.80 \text { vs. } 2.14 \pm 0.87, \mathrm{P}=0.001 \\
\text { Contralateral MF: } 5.38 \pm 9.96 \text { vs. } 1.96 \pm 1.06, \mathrm{P}=0.037 \text {. } \\
\text { Delayed core muscle contraction: } \\
\text { LBP patients has increased rapid reaction time }(\mathrm{RRT}) \\
\text { on ES muscles (ipsilateral \& contralateral) and } \mathrm{MF} \\
\text { muscles (contralateral) }(\mathrm{P}<0.05) \text {. }\end{array}$ & $\begin{array}{l}\text { People w LBP has increased core activa- } \\
\text { tion amplitude \& delayed core muscle } \\
\text { contraction during imbalance conditions. }\end{array}$ \\
\hline 2 & $\begin{array}{l}\text { Seay et } \\
\text { al. [11] }\end{array}$ & $\begin{array}{l}\mathrm{N}=18 \\
\text { Male soldiers } \\
\text { History of back pain } \\
\text { (HBP): } \mathrm{N}=9 \\
\text { No history of back pain } \\
\text { (NBP): } \mathrm{N}=9\end{array}$ & $\begin{array}{l}\text { Trunk ROM and BP } \\
\text { Minute 1: } \\
\text { ROM were similar for both HBP and NBP. } \\
\text { Minute 9: } \\
\text { - } \quad \text { HBP group - no change in ROM }(31.9 \pm 9 \mathrm{deg}) \text {; } \\
\quad \text { NBP group decreased ROM }(21.6 \pm 6 \mathrm{deg}, \mathrm{p}< \\
\text { 0.05). }\end{array}$ & $\begin{array}{l}\text { People w no history of back pain has } \\
\text { increasing Pelvic \& trunk ROM over } \\
\text { time during lifting and lowering task. } \\
\text { No changes were noted in people w } \\
\text { history of back pain. }\end{array}$ \\
\hline
\end{tabular}

Table 3: Epidemiology studies: identified risk factors for LBP in military personnel/recruits

\begin{tabular}{|l|l|l|l|l|l|l|l|}
\hline No & Author (s) & Branch of services & Country & Results & \multicolumn{3}{|l|}{ Risk factors identified } \\
\cline { 5 - 7 } & & & & Personnel & Occupational \\
\hline 1. & $\begin{array}{l}\text { Monnier et } \\
\text { al. [12] }\end{array}$ & Marines & Sweden & $\begin{array}{l}\text { Association to BP } \\
6 \text { Months: (Risk fac- }\end{array}$ & $\begin{array}{l}\text { History of } \\
\text { BP. }\end{array}$ & \\
\hline
\end{tabular}




\begin{tabular}{|c|c|c|c|c|c|c|c|}
\hline & & & & 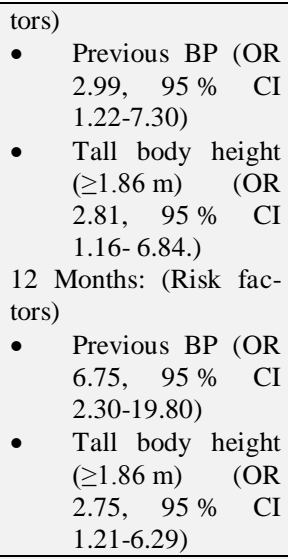 & $\begin{array}{ll} & \text { Tall body } \\
\text { height } \\
(\geq 1.86 \mathrm{~m})\end{array}$ & & \\
\hline 2. & $\begin{array}{l}\text { Bar-Dayan } \\
\text { et al. [13]. }\end{array}$ & Military recruits & Israel & $\begin{array}{l}\text { Association to LBP: } \\
\begin{array}{l}\text { - Female Gender } \\
(\mathrm{OR} 1.93, \quad \mathrm{CI} \\
1.89-1.98)\end{array}\end{array}$ & $\begin{array}{l}\text { - Female } \\
\text { Gender }\end{array}$ & & \\
\hline 3. & $\begin{array}{l}\text { Bongers et } \\
\text { al. [14] }\end{array}$ & $\begin{array}{l}\text { Military helicopter } \\
\text { pilots }\end{array}$ & $\mathrm{n} / \mathrm{a}$ & $\begin{array}{l}\text { Association to LBP } \\
\text { - } \quad \text { Transient back } \\
\text { pain and average } \\
\text { hours of flight per } \\
\text { day (OR: } 11.3, \text { CI } \\
\text { 5.2-24.8). } \\
\text { Association with } \\
\text { CLBP } \\
\text { Chronic back pain } \\
\text { related to total } \\
\text { hours of flight \& } \\
\text { the accumulative } \\
\text { vibration dose } \\
\text { (p<0.01). }\end{array}$ & & $\begin{array}{l}\text { - } \begin{array}{l}\text { Hours of flight } \\
\text { per day }\end{array} \\
\text { - Whole body } \\
\text { vibration }\end{array}$ & \\
\hline 4. & $\begin{array}{l}\text { Ernat et al. } \\
{[15]}\end{array}$ & Army \& Marines & $\mathrm{n} / \mathrm{a}$ & $\begin{array}{l}\text { Association to acute } \\
\text { LBP } \\
\bullet \quad \text { Age: IRR } \\
<20.0: 0.63 \\
20-24 \text { y/o: } 0.58 \\
25-29 \text { y/o: } 0.72 \\
30-34 \text { y/o: } 0.83 \\
35-39 \text { y/o: } 0.88 \\
\geq 40 \text { y/o: } 0.91 \\
\bullet \quad \text { Race: IRR } \\
\text { Whites }(0.67) \\
\text { blacks }(0.77), \\
\text { Other (0.65) } \\
\bullet \quad \text { Marital } \\
\text { status: IRR } \\
\text { singles }(0.61) \\
\text { married (0.76) } \\
\text { others }(0.67) \\
\bullet \quad \text { Rank: IRR } \\
\text { junior (0.59) } \\
\text { senior enlistees } \\
\text { (0.80) } \\
\bullet \quad \text { Branch of } \\
\text { Army (0.70) } \\
\text { Marines }(0.59) \\
\end{array}$ & $\begin{array}{ll}- & \text { Older Age } \\
- & \text { Race } \\
& \text { (Blacks) } \\
-\quad & \text { marital } \\
& \text { status } \\
& \text { (Married) }\end{array}$ & $\begin{array}{l}\text { - } \begin{array}{l}\text { Higher Rank } \\
\text { (Senior Enlist- } \\
\text { ees) } \\
\text { Branch of ser- } \\
\text { vice (army) }\end{array} \\
\end{array}$ & \\
\hline 5. & $\begin{array}{l}\text { Feuerstein et } \\
\text { al. [16] }\end{array}$ & $\begin{array}{ll}\text { Army: } \\
\text { - } \quad \text { Infantry } \\
\text { - Wheel Vehi- } \\
\text { cle Driver } \\
\text { - Construction } \\
\text { Equipment } \\
\text { repairer } \\
\text { - Wheeled } \\
\text { Vehicle Me- } \\
\text { chanic } \\
\text { Multi- } \\
\text { channel } \\
\text { Transmission } \\
\text { Systems op- } \\
\end{array}$ & U.S. & $\begin{array}{ll}\text { Association to LBP } \\
\text { - } \quad \text { Female gender } \\
(\mathrm{OR}=6.59, \mathrm{CI} \\
1.79-24.24, \mathrm{p}< \\
0.01) \\
\text { Education beyond } \\
\text { HS/ GED (OR = } \\
3.60, \mathrm{CI}=1.77- \\
7.32, \mathrm{P}<0.01) \\
\text { Longer time } \\
\text { working in mili- } \\
\text { tary }(\mathrm{OR}=1.29, \\
\mathrm{CI}=1.08-1.54, \\
\mathrm{p}<0.01)\end{array}$ & $\begin{array}{ll}-\quad \text { Female } \\
\text { Gender } \\
\text { Higher } \\
\text { Education } \\
\text { level } \\
\text { Longer } \\
\text { Service } \\
\text { time } \\
\text { Rare/never } \\
\text { Aerobic } \\
\text { exercise } \\
\text { involve- } \\
\text { ment }\end{array}$ & $\begin{array}{l}\text { Higher Ergo- } \\
\text { nomic exposure }\end{array}$ & $\begin{array}{ll}\text { - } & \text { Worries } \\
\text { - } & \text { Low Moral } \\
\text { - } & \text { Higport Work } \\
& \text { stress } \\
\text { - } & \text { Increased Peer } \\
\text { cohesion } \\
\text { - Greater Per- } \\
\text { ceived effort } \\
\text { at work }\end{array}$ \\
\hline
\end{tabular}




\begin{tabular}{|c|c|c|c|c|c|c|c|}
\hline & & $\begin{array}{ll} & \text { erator } \\
\text { - } & \text { Practical } \\
\text { Nurse }\end{array}$ & & $\begin{array}{l}\text { Rarely/never } \\
\text { participating in } \\
\text { aerobic exercise } \\
\text { (OR 4.39, CI } 1.53 \\
\text {-12.57, } \mathrm{p}<0.01), \\
\text { Higher levels of } \\
\text { interference from } \\
\text { worries in daily } \\
\text { life }(\mathrm{OR}=5.47, \\
\mathrm{CI} 1.70-17.62, \\
\mathrm{p}<0.01) \\
\text { No support from } \\
\text { others }(\mathrm{OR}=4.01, \\
\mathrm{CI}=1.31-12.34, \\
\mathrm{p}<0.05), \\
\text { higher levels of } \\
\text { ergonomic expo- } \\
\text { sure }(\mathrm{OR}=1.08, \\
\mathrm{CI}=1.03-1.13, \\
\mathrm{p}<0.01), \quad \\
\text { work situation } \\
\text { perceived as } \\
\text { sometimes stress- } \\
\text { ful) OR }=3.47, \mathrm{CI} \\
=1.24 \quad 9.74, \\
\mathrm{p}<0.05), \\
\text { lower levels of } \\
\text { innovation }(\mathrm{OR}= \\
0.76, \mathrm{CI} 0.64- \\
0.90, \mathrm{P}<0.05), \text { in- } \\
\text { volvement (OR } \\
0.81, \mathrm{CI}=0.66- \\
0.99, \mathrm{P}<0.05), \\
\text { supervisor sup- } \\
\text { port }(\mathrm{OR}-0.78, \\
\mathrm{CI}=0.64-0.95, \\
\mathrm{P}<0.05), \\
\text { increased peer } \\
\text { cohesion } \\
(\mathrm{OR}=1.22, \mathrm{CI}= \\
1.01-1.47, \\
\mathrm{P}<0>05) \\
\text { greater perceived } \\
\text { effort at work } \\
(\mathrm{OR}=1.48, \mathrm{CI}= \\
1.27-1.73, \\
\mathrm{P}<0.001) . \\
\text { - }\end{array}$ & & & \\
\hline 6. & $\begin{array}{l}\text { Feuerstein et } \\
\text { al. [17] }\end{array}$ & Army & U.S. & 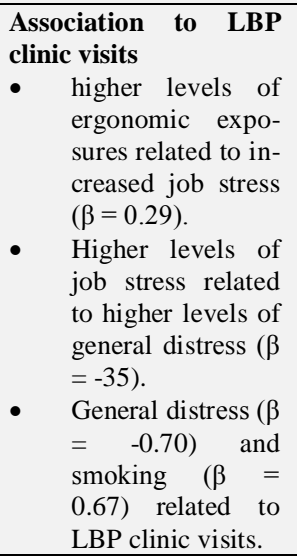 & - $\quad$ Smoking & & $\begin{array}{ll} & \begin{array}{l}\text { General dis- } \\
\text { tress }\end{array}\end{array}$ \\
\hline 7. & $\begin{array}{l}\text { George et al. } \\
{[18]}\end{array}$ & Army & U.S. & $\begin{array}{l}\text { Association to LBP } \\
\text { Gender (p = } \\
0.0002) \\
\text { Active duty }(\mathrm{p}= \\
0.012) \\
\text { Mental and physi- } \\
\text { cal health scores } \\
\text { (Beck depression } \\
\text { inventory, p = } \\
0.002 ; \text { Fear of } \\
\text { Pain Question- } \\
\text { naire }(\mathrm{p}=0.04)\end{array}$ & $\begin{array}{ll}- & \text { Female } \\
& \text { Gender } \\
\text { - } & \text { Physical } \\
& \text { health }\end{array}$ & - $\quad$ Active duty & - $\quad$ Mental health \\
\hline
\end{tabular}




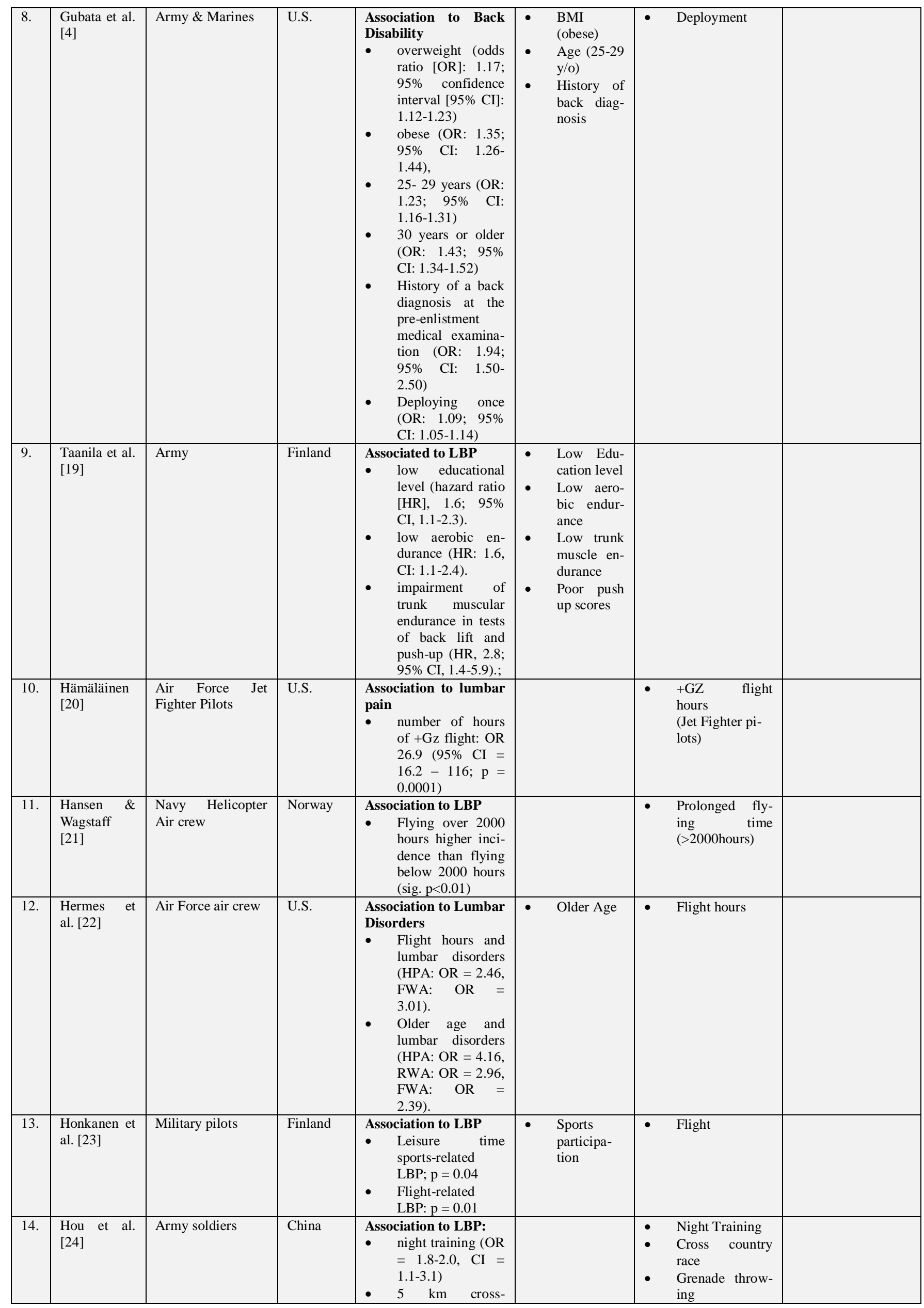




\begin{tabular}{|c|c|c|c|c|c|c|c|}
\hline & & & & $\begin{array}{l}\text { country race }(\mathrm{OR} \\
=1.6-1.8, \mathrm{CI}= \\
1.1-2.3) \\
\text { grenade-throwing } \\
\text { training }(\mathrm{OR}= \\
1.6-1.7, \text { CI } 0.9- \\
2.2)\end{array}$ & & & \\
\hline 15. & $\begin{array}{l}\text { Knox et al. } \\
{[25]}\end{array}$ & $\begin{array}{ll}\text { Military } & \text { service } \\
\text { members } & \end{array}$ & U.S. & $\begin{array}{l}\text { Association to LBP } \\
\text { - Age: } \\
\text { Native Ameri- } \\
\text { cans/Alaskan } 126 \% \\
\text { IRR difference (young- } \\
\text { est to oldest) } \\
\text { Whites: } 36 \% \text { IRR dif- } \\
\text { ference (youngest to } \\
\text { oldest) } \\
\text { - Race: } \\
\text { Asians/Pacific Islanders } \\
\text { (IRR = 30.7) } \\
\text { Blacks (IRR = 43.7). } \\
\text { Female sex and older } \\
\text { age were also signifi- } \\
\text { cant risk factors but } \\
\text { with significantly dif- } \\
\text { ferent effect sizes be- } \\
\text { tween racial groups. . }\end{array}$ & $\begin{array}{ll} & \text { Race } \\
\text { (Blacks) } \\
-\quad \text { Female } \\
\text { gender } \\
\text { - } \\
\text { Older Age }\end{array}$ & & \\
\hline 16. & $\begin{array}{l}\text { Knox et al. } \\
{[9]}\end{array}$ & $\begin{array}{ll}\begin{array}{l}\text { Military } \\
\text { members }\end{array} & \text { service } \\
\end{array}$ & U.S. & $\begin{array}{ll}\text { Association to LBP } \\
\text { - } & \text { Female (IRR = } \\
& 1.45) \\
\text { - } & 40+\text { age group } \\
& \text { (IRR = 1.29) } \\
\text { - } \quad \text { junior-enlisted } \\
\text { (1RR = 1.95) sen- } \\
\text { ior-enlisted (IRR } \\
\text { = 1.35) } \\
\text { Army: (IRR: } 2.19) \\
\text { Navy (IRR: } 1.02) \\
\text { Air Force (IRR = } \\
\text { 1.54.) } \\
\text { Married (IRR = } \\
\text { 1.21) }\end{array}$ & $\begin{array}{ll}- & \text { Female } \\
& \text { Gender } \\
- & \text { Older Age } \\
\text { - } & \text { Marital } \\
& \text { Status }\end{array}$ & $\begin{array}{l}\text { Branch of Ser- } \\
\text { vice (Army) }\end{array}$ & \\
\hline 17. & $\begin{array}{l}\text { Knox et al. } \\
{[26]}\end{array}$ & $\begin{array}{ll}\begin{array}{l}\text { Military } \\
\text { members }\end{array} & \text { service } \\
\end{array}$ & U.S. & $\begin{array}{l}\text { Associated to LBP } \\
\text { Motor vehicle } \\
\text { operators IRR = } \\
1.15 \text { (95\% CI = } \\
1.13-1.17) \text { when } \\
\text { compared to oth- } \\
\text { ers } \\
\text { Female motor } \\
\text { vehicle operators, } \\
\text { compared with } \\
\text { males, LBP IRR = } \\
1.45 \text { (95\% CI } \\
1.39-1.52) . \\
\text { Junior enlisted } \\
\text { when compared to } \\
\text { senior enlisted } \\
\text { rank group = IRR } \\
=1.60 \text { (95\% CI } \\
1.52-1.70) . \\
\text { Army, 2.74 (95\% } \\
\text { CI 2.60-2.89), and } \\
\text { the Air Force, } \\
1.98 \quad(95 \% \text { CI } \\
1.84-2.14) \text { when } \\
\text { compared to Ma- } \\
\text { rine. } \\
\text { Age: compared w } \\
30-39 \text { y/o } \\
<20-y e a r \text { IRR = } \\
1.24(1.15-1.36) \\
\text { 40-year age groups } \\
\text { IRR = } 1.23(1.10-1.38),\end{array}$ & $\begin{array}{ll}- & \text { Older Age } \\
& \text { Female } \\
\text { gender }\end{array}$ & $\begin{array}{ll}\text { - } & \text { Branch of ser- } \\
\text { vice(Army) } \\
\text { - } \\
\text { Rank (Junior } \\
\text { enlisted) } \\
\text { - Occupational } \\
\text { driving }\end{array}$ & \\
\hline 18. & $\begin{array}{l}\text { Seay et al. } \\
{[27]}\end{array}$ & Army soldiers & U.S. & $\begin{array}{l}\text { Associated to LBP: } \\
\text { - Lower extremity } \\
\text { injury (LEI) HR } \\
1.7,95 \% \text { CI } 1.66,\end{array}$ & $\begin{array}{ll}\quad \text { Lower } \\
\text { extremity } \\
\text { injury }\end{array}$ & & \\
\hline
\end{tabular}




\begin{tabular}{|c|c|c|c|c|c|c|c|}
\hline & & & & 1.74) & & & \\
\hline 19. & $\begin{array}{l}\text { Kang et al. } \\
{[28]}\end{array}$ & Army soldiers & Korea & $\begin{array}{l}\text { Association to LBP } \\
\text { - } \quad \text { military rank } \rightarrow \\
\text { inverse correlation } \\
\text { with the VAS } \\
\text { scores and the } \\
\text { ODI }(\mathrm{P}<0.05) \text {; } \\
\text { Highest } \rightarrow \text { Low- } \\
\text { est clinical value } \\
\text { Privates } \\
7.2 \% \pm 1.1 \% \text {, (VAS- } \\
\text { LBP) } \\
8.0 \% \pm 1.2 \%, \text { (VAS - } \\
\text { LP) } 61.7 \% \pm 9.2 \%, \text { (ODI) } \\
\text { Sergeants: } \\
\text { 5.8\% } \pm 2.0 \%, \text { (VAS- } \\
\text { LBP) } \\
6.4 \% \pm 2.6 \%, \text { (VAS - } \\
\text { LP) } \\
37.3 \% \pm 14.5 \%, \text { (ODI) }\end{array}$ & & $\begin{array}{lll}\text { - } & \text { Military } & \text { rank } \\
& \text { (Privates) } & \end{array}$ & \\
\hline 20. & $\begin{array}{l}\text { Kardouni et } \\
\text { al. [29] }\end{array}$ & Army soldiers & U.S. & 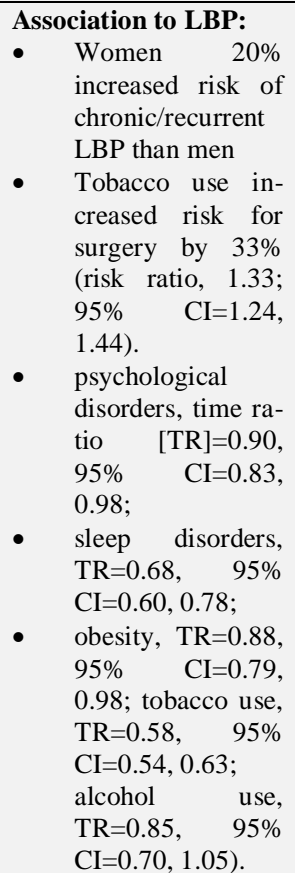 & $\begin{array}{ll}- & \text { Obesity } \\
\text { - } & \text { Tobacco } \\
& \text { use } \\
\text { - } & \text { Alcohol } \\
& \text { use } \\
& \\
\end{array}$ & & $\begin{array}{l}\text { - } \begin{array}{l}\text { Mental health } \\
\text { Sleep disor- } \\
\text { ders }\end{array} \\
\end{array}$ \\
\hline 21. & $\begin{array}{l}\mathrm{Mu} \text { et al. } \\
{[30]}\end{array}$ & Army soldiers & China & $\begin{array}{l}\text { Association to LBP } \\
\text { G allele of CASP- } \\
9 \& \mathrm{~T} \text { allele of } \\
\text { GDF5 are com- } \\
\text { mon in LBP group } \\
\text { than controls (p < } \\
0.001, \text { OR } 2.059, \\
95 \% \text { CI } 1.689- \\
2.512 \text { and p < } \\
0.001, \text { OR } 2.115, \\
95 \% \text { CI } 1.662- \\
2.692) . \\
\text { Carriers of the G } \\
\text { allele (GG+AG) } \\
\text { of the CASP-9 \& } \\
\text { T allele (TT+TC) } \\
\text { of GDF5 are } \\
\text { common in LBP } \\
\text { groups than con- } \\
\text { trol groups (p < } \\
0.001, \text { OR } 0.436, \\
95 \% \text { CI } 0.314- \\
0.604 \text { and p }= \\
0.0004, \text { OR } 0.309, \\
95 \% \text { CI } 0.156- \\
0.614) \text {. } \\
\text { GG of CASP-9 } \\
\text { and TT of GDF5 } \\
\text { significant rela- }\end{array}$ & - $\quad$ Genetic & - $\quad$ Military training & \\
\hline
\end{tabular}




\begin{tabular}{|c|c|c|c|c|c|c|c|}
\hline & & & & $\begin{array}{l}\text { tionship to LBP } \\
\text { related to military } \\
\text { training (p < } \\
0.001 \text {, OR } 3.136 \text {, } \\
95 \% \text { CI } 2.237- \\
4.397 \text { and p < } \\
0.001 \text {, OR } 2.361 \text {, } \\
95 \% \text { CI } 1.768- \\
3.153) \text {. }\end{array}$ & & & \\
\hline 22. & $\begin{array}{l}\text { Nelson et al. } \\
{[31]}\end{array}$ & Military nurses & U.S. & $\begin{array}{l}\text { Association to LBP } \\
\text { Female only } \rightarrow \\
\text { - } \quad \text { Prior depression: } \\
\text { OR } 1.75 \text {, CI } 1.08- \\
2.83, \mathrm{P}<0.05) \text {. } \\
\text { Male and female } \rightarrow \\
(\mathrm{p}<0.05) \\
\text { - } \quad \text { BMI } \geq 30 \mathrm{~kg} / \mathrm{m} 2 \\
\text { - } \quad \text { Prior combat } \\
\text { - deployments } \\
\text { Age } \geq 36 \text { years old }\end{array}$ & $\begin{array}{ll}- & \begin{array}{l}\text { Older Age } \\
(>36 \text { y/o) }\end{array} \\
\text { BMI } \\
\text { (obese) }\end{array}$ & $\begin{array}{ll}\text { - } & \begin{array}{l}\text { Combat } \\
\text { ployment }\end{array}\end{array}$ & - Depression \\
\hline 23. & $\begin{array}{l}\text { Nissen et al. } \\
{[7]}\end{array}$ & Army soldiers & Denmark & 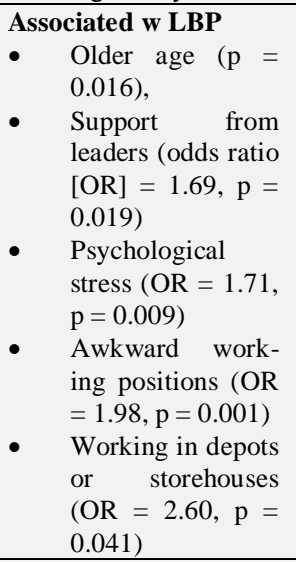 & - $\quad$ Older Age & $\begin{array}{l}\text { - Work positions } \\
\text { (Awkward) } \\
\text { Work station } \\
\text { (de- } \\
\text { pots/storehouses } \\
\text { ) }\end{array}$ & $\begin{array}{l}\text { - Leader Social } \\
\text { Support } \\
\text { Psychological } \\
\text { Stress } \\
\end{array}$ \\
\hline 24. & $\begin{array}{l}\text { O'Connor \& } \\
\text { Marlowe } \\
{[32] .}\end{array}$ & Army soldiers & U.S. & $\begin{array}{l}\text { Association to LBP: } \\
\text { - } \quad \text { Smokers are more } \\
\text { likely to develop } \\
\text { LBP as compared } \\
\text { to non-smokers (p } \\
=0.02)\end{array}$ & $\begin{array}{l}\text { Smoking } \\
\text { habits }\end{array}$ & & \\
\hline 25. & $\begin{array}{l}\text { Orsello et al. } \\
\text { [33] }\end{array}$ & $\begin{array}{l}\text { Navy helicopter } \\
\text { pilots }\end{array}$ & U.S. & $\begin{array}{l}\text { Associated to LBP } \\
\text { - } \quad \text { Height (OR: } 1.7) \\
\text { Male pilots (OR: } \\
\text { 2.1) }\end{array}$ & $\begin{array}{ll}- & \text { Tall Height } \\
\text { Male Gen- } \\
\text { der }\end{array}$ & & \\
\hline 26. & $\begin{array}{l}\text { Roy \& } \\
\text { Lopez [34] }\end{array}$ & $\begin{array}{l}\text { Combat army } \\
\text { soldiers }\end{array}$ & U.S. & $\begin{array}{l}\text { Association to LBP } \\
\text { - BSB battalion } \\
\text { History of LBP (OR } \\
5.034, \text { CI } 1.61-15.72) \\
\text { Lifting (OR 1.3, CI } \\
\text { 1.06-1.6) } \\
\text { - BSTB battalion } \\
\text { History of LBP (OR } \\
8.91, \text { CI } 1.71-46.5) \\
\text { Strength training (OR } \\
0.86, \text { CI } 0.78-0.99) \\
\text { Body armour (OR } 1.23 \text {, } \\
\text { CI 1.03-1.47) } \\
\text { - RSTA battalion } \\
\text { Body armour (OR } 1.3 \text {, } \\
\text { CI 1.11-1.5) } \\
\text { History of LBP (OR } \\
\text { 2.2, CI 1.2-4.0) }\end{array}$ & $\begin{array}{l}\text { - History of } \\
\text { LBP }\end{array}$ & $\begin{array}{ll} & \text { Lifting } \\
\text { - } & \text { Strength train- } \\
& \text { ing } \\
\text { - } & \text { Body armour } \\
& \end{array}$ & \\
\hline 27. & $\begin{array}{l}\text { Roy et al. } \\
{[35]}\end{array}$ & $\begin{array}{l}\text { Combat army } \\
\text { soldiers }\end{array}$ & U.S. & $\begin{array}{l}\text { Associated to (moder- } \\
\text { ate or worse) LBP: } \\
\text { - } \quad \text { Age, OR = } 1.04 \\
(1.01-1.08) \\
\text { - } \quad \begin{array}{l}\text { Fitness score, OR } \\
=0.99 \quad(0.989- \\
0.999) \\
\text { - The amount of }\end{array} \\
\end{array}$ & $\begin{array}{ll}- & \text { Age } \\
-\quad & \text { Fitness } \\
& \text { level }\end{array}$ & $\begin{array}{l}\text { - } \begin{array}{l}\text { Duration body } \\
\text { armour usage }\end{array} \\
\text { Weight of } \\
\text { equipment worn } \\
\text { - } \\
\text { Patrol duration }\end{array}$ & \\
\hline
\end{tabular}




\begin{tabular}{|c|c|c|c|c|c|c|c|}
\hline & & & & $\begin{array}{l}\text { time spent wear- } \\
\text { ing body armor, } \\
\text { OR }=1.16(1.10- \\
1.23) ; \\
\text { The amount of } \\
\text { time spent on } \\
\text { walking patrol, } \\
\text { OR = 1.01 (1.003- } \\
1.02) ; \\
\text { Weight of the } \\
\text { equipment worn, } \\
\text { OR = } 1.01(1.002- \\
1.013) . \\
\text { Associated to (for all } \\
\text { types) } \text { LBP } \\
\text { Age, OR = } 1.06 \\
\text { (1.02-1.09); } \\
\text { Fitness score, OR } \\
=0.99 \quad(0.985- \\
\text { 0.997) } \\
\text { History of LBP, } \\
\text { OR = 2.94, (1.87- } \\
4.62) \\
\text { Equipment } \\
\text { weight, OR = } \\
1.008(1.003-1.01) \\
\text { Time spent wear- } \\
\text { ing body armour, } \\
\text { OR = } 1.13(1.07- \\
1.19) .\end{array}$ & & & \\
\hline 28. & $\begin{array}{l}\text { Rozali et al. } \\
{[36]}\end{array}$ & $\begin{array}{ll}\text { Army } & \text { vehicle } \\
\text { driver } & \end{array}$ & Malaysia & $\begin{array}{l}\text { Association to cLBP } \\
\text { (LBP > 12 months) } \\
\text { - } \quad \text { Driving in for- } \\
\text { ward bending sit- } \\
\text { ting posture (OR } \\
=3.63,95 \% \text { CI } \\
1.06-12.42) \\
\text { WBV exposure at } \\
\text { X-axis (OR = } \\
1.94,95 \% \text { CI } \\
1.02-3.69)\end{array}$ & & $\begin{array}{l}\text { - } \begin{array}{l}\text { Forward bend } \\
\text { Sitting posture } \\
\text { Whole body } \\
\text { vibration }\end{array} \\
\end{array}$ & \\
\hline 29. & $\begin{array}{l}\text { Secer et al. } \\
{[37]}\end{array}$ & Army soldiers & Turkey & $\begin{array}{l}\text { Associatedto LBP } \\
\text { - } \quad \text { Monthly income } \\
\text { and Labour condi- } \\
\text { tion }(\mathrm{P}>0.05) \\
83.69 \% \text { LBP } \\
\text { participants had } \\
\text { Psychological } \\
\text { problems (p < } \\
0.05)\end{array}$ & $\begin{array}{l}\text { Monthly } \\
\text { income }\end{array}$ & $\begin{array}{l}\text { - Labour condi- } \\
\text { tions }\end{array}$ & 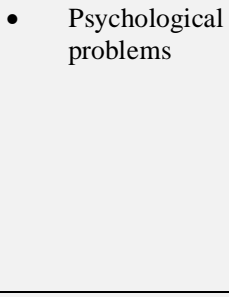 \\
\hline 30. & $\begin{array}{l}\text { Tvaryanas et } \\
\text { al. [38] }\end{array}$ & $\begin{array}{l}\text { Air Force service } \\
\text { members }\end{array}$ & U.S. & 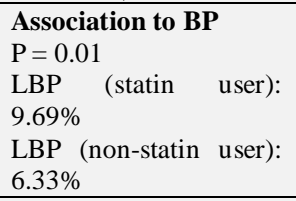 & $\begin{array}{l}\text { Statin } \\
\text { usage }\end{array}$ & & \\
\hline 31. & $\begin{array}{l}\text { Mattila et al. } \\
\text { [39] }\end{array}$ & Army conscripts & Finland & $\begin{array}{l}\text { Association to LBP } \\
\text { LBP history: } 2 \text { or } \\
\text { more other than } \\
\text { back-related dis- } \\
\text { eases (OR 2.0; } \\
95 \% \text { CI 1.6-2.5), } \\
\text { Below-average } \\
\text { self-perceived } \\
\text { health (OR 1.6; } \\
\text { 95\% CI 1.3-2.0) } \\
\text { Use of smokeless } \\
\text { tobacco (OR 1.4; } \\
\text { 95\% CI 1.2-1.7). }\end{array}$ & $\begin{array}{l}\text { - Health } \\
\text { status } \\
\text { LBP His- } \\
\text { tory } \\
\text { - Smokeless } \\
\text { Tobacco } \\
\text { usage }\end{array}$ & & \\
\hline
\end{tabular}

Table 4: Summary of identified LBP risk factors in the Military

\begin{tabular}{|c|c|c|}
\hline Personal risk factors & Occupational risk factors & Psychosocial risk factors \\
\hline 1. Age $(25-29 \mathrm{y} / \mathrm{o})$, & 1. $\quad$ Active duty & 1. Worries \\
\hline Older Age $(>36 \mathrm{y} / \mathrm{o})$ & Deployment & Low Moral support \\
\hline 3. $\mathrm{G}$ allele of CASP-9 \& $\mathrm{T}$ allele of GDF5 & 3. Combat Deployment & Mental health \\
\hline genetics & 4. Rank (Junior enlisted) & 4. High Work stress \\
\hline 4. Female Gender & 5. Higher Ergonomic exposure & 5. Psychological Stress \\
\hline
\end{tabular}




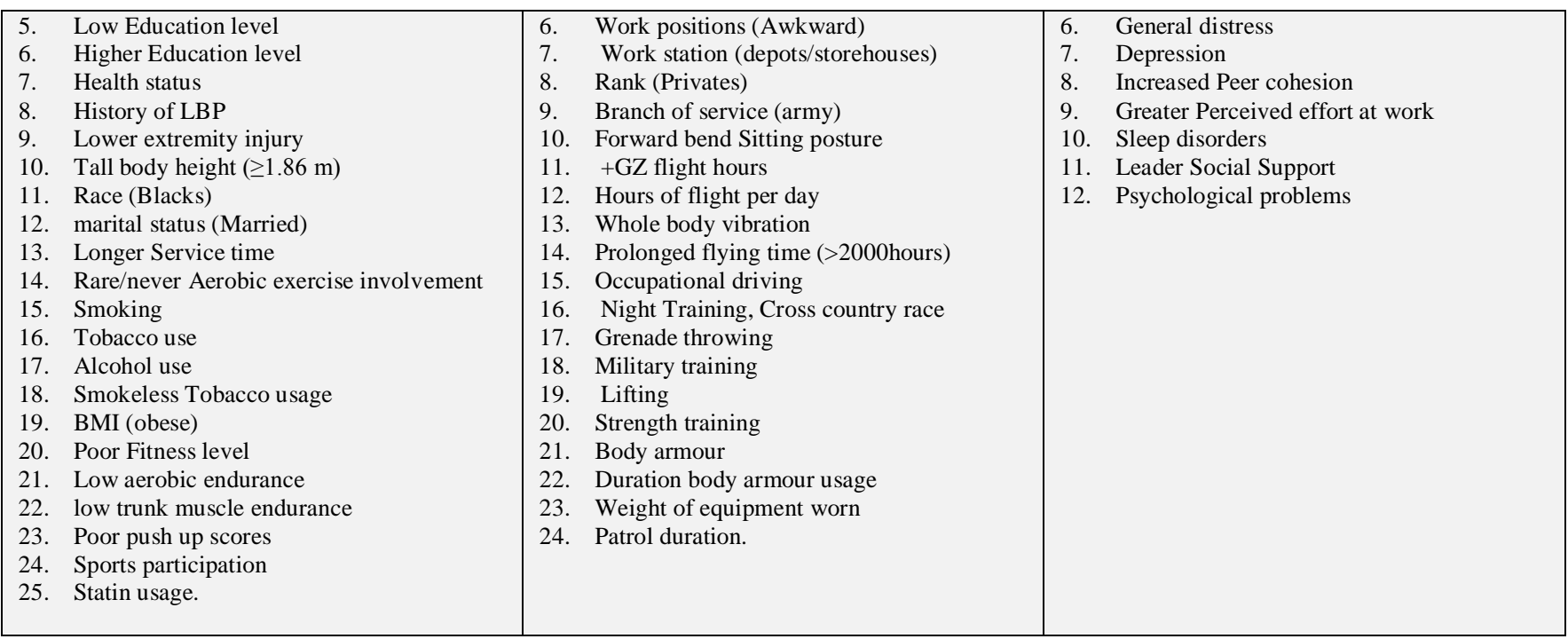

